\title{
ANALYSIS OF THE SURFACE-PREPARATION EFFECT ON THE HARDNESS-MEASUREMENT UNCERTAINTY OF ALUMINIUM ALLOYS
}

\author{
VPLIV PRIPRAVE POVRŠINE PRI MERITVAH TRDOTE TER \\ IZRAČUNIH MERILNE NEGOTOVOSTI ZA ALUMINIJEVE \\ ZLITINE
}

\author{
Agnieszka Guštin ${ }^{1 *}$, Marko Sedlaček ${ }^{1}$, Borut Žužek ${ }^{1}$, Bojan Podgornik ${ }^{1}$, \\ Varužan Kevorkijan ${ }^{2}$ \\ ${ }^{1}$ Institute of Metals and Technology, Lepi pot 11, 1000, Ljubljana, Slovenia \\ 2Impol aluminium Industry, Partizanska 38, 2310 Slovenska Bistrica, Slovenia \\ Prejem rokopisa - received: 2020-01-07; sprejem za objavo - accepted for publication: 2020-08-05
}

doi:10.17222/mit.2020.008

\begin{abstract}
Surface roughness has a strong effect on the measurement uncertainty and scatter of results in instrumented indentation hardness testing. Thus, it is an important factor to take into account when planning experimental parameters. This research was focused on selecting the appropriate hardness method together with the surface preparation that would provide the best measurement accuracy. The material used for this investigation was a 2xxx-series aluminium alloy 2030 ( $\mathrm{AlCuMgPb})$ in the $\mathrm{T} 6$ condition, manufactured from one batch of homogenous material. The hardness measurements were performed using three different hardness methods: Brinell, Vickers and Rockwell. The analysis was first focused on the impact of the different surface-preparation parameters, performed on milled square blocks of aluminium alloy. The hardness tests were performed on samples with different surface preparations in which the surface milling parameters including rotation speed of the cutting mill, the feed rate and the depth of cut, were varied. Secondly, the impact of surface curvature was investigated by performing hardness measurements on cylinders with different diameters, manufactured from aluminium blocks. The statistical deviation of the obtained measurement results is graphically presented and discussed. Based on the obtained measurement-uncertainty results, it is concluded that the best measurement accuracy is achieved when the surface roughness is less than $S_{\mathrm{a}}<0.6 \mu \mathrm{m}$ and $S_{\mathrm{z}}<10 \mu \mathrm{m}$ for the Brinell and Rockwell tests, while the Vickers test requires additional grinding or polishing of the surface.

Keywords: hardness measurements, surface preparation, roughness, measurement uncertainty, aluminium alloy
\end{abstract}

Hrapavost površine vzorcev močno vpliva na merilno negotovost in raztros rezultatov pri instrumentiranem merjenju trdote. Zaradi tega je hrapavost površine pomemben dejavnik, ki ga je potrebno upoštevati pri načrtovanju parametrov meritev trdote. Z namenom določiti najboljšo natančnost merjenja trdote se je ta raziskava osredotočila na izbiro ustrezne metode merjenja vključujoč z različno pripravo površine vzorca. Za ta namen smo uporabili aluminijevo zlitino serije $2030(\mathrm{AlCuMgPb}) \mathrm{v}$ stanju T6, izdelane iz ene sarže homogenega materiala. Meritve trdote so bile izvedene s tremi različnimi metodami merjenja trdote: Brinell, Vickers in Rockwell. Raziskava je bila najprej osredotočena na vpliv različnih parametrov priprave površine, izvedenih na rezkanih kvadratnih blokih iz aluminijeve zlitine. Meritve trdote so bile izvedene na vzorcih z različno pripravljeno površino, ki je bila dosežena s spreminjanem parametrov rezkanja, vključujoč hitrost vrtenja frezala, hitrost podajanja in globino reza. V drugem sklopu smo preučili vpliv ukrivljenosti površine na izmerjeno trdoto. $\mathrm{V}$ ta namen smo uporabili aluminijaste valjčke $\mathrm{z}$ različnimi premeri. Statistična analiza rezultatov meritev je grafično predstavljena in obravnavana. Na podlagi rezultatov merilne negotovosti je bilo ugotovljeno, da dosežemo najboljšo natančnost meritev, če je hrapavost površine $S_{a}<0,6 \mu \mathrm{m}$ in $S_{z}<$ $10 \mu \mathrm{m}$ za meritev trdote po Brinell-u in Rockwell-u, medtem, ko meritev trdote po Vickers-u zahteva dodatno brušenje ali poliranje površine.

Ključne besede: hrapavost, meritve trdote, priprava površine, merilna negotovost

\section{INTRODUCTION}

Mechanical testing is often used for material assessment, in research and development work, and in quality control of a production process. ${ }^{1}$ The hardness test is an example of mechanical testing and material properties determination that is used in engineering design, the analysis of structures, and materials development.

Hardness testing is of prime importance in industry and industrial laboratories, where the time from receiving material to the delivery of reliable hardness measure-

*Corresponding author's e-mail:

agnieszka.gustin@imt.si (Agnieszka Guštin) ment results is extremely important. In an attempt to shorten lead times there is a high risk of using improper surface machining and preparation, which can lead to incorrect or false results. Different hardness-measurement methods are also differently dependent on the surface quality, some being more sensitive than the others. ${ }^{2}$ Therefore, optimal surface machining and preparation, combined with the appropriate hardness testing method, ${ }^{3}$ is required in industry to provide fast but reliable results with a low measurement uncertainty. ${ }^{4}$

The principal purpose of the hardness test is to determine the strength and suitability of a material for a given application, or the particular treatment to which the material has been subjected. ${ }^{5} \mathrm{~A}$ hardness test is typically 
performed by pressing a specifically dimensioned and loaded object (indenter) into the surface of the material being tested. The hardness is determined by measuring the depth of indenter's penetration or by measuring the size of the impression left by an indenter. The required surface condition depends on the type of test and the load used. Selection of the type of the hardness test is significantly affected by the quality of the surface preparation, which is extremely important in instrumented indentation testing, because the mechanical properties of the tested material are estimated on the assumption that the sample surface is perfectly flat and smooth. However, no surface is perfectly flat, and every surface has a certain degree of roughness. Therefore, the information on the surface roughness and topography becomes increasingly important in testing.

Surface roughness ${ }^{6,7}$ can be defined as a complex combination of irregularities and little indents that characterize a surface. It presents a complex shape made of a series of peaks and valleys of varying heights, depths, and spacings. Surface finish - also known as profile or topography - is composed of two elements: waviness and roughness. The roughness of the sample surface ${ }^{8}$ can be a serious source of errors in the determination of properties from indentation tests. In practice, when the indenter comes into contact with a peak, the non-uniform contact increases the localized stress at the points of contact, deforming the material to a greater depth at relatively low loads. This can result in a greater penetration depth and lower calculated hardness. If the indenter comes into contact with a valley, the opposite phenomenon is observed, i.e., the true contact area is underestimated and, consequently, the calculated hardness is overestimated. If the surface has some big peaks in it, the indenter will hit these first, then work through lesser peaks before it gets to the "real" surface.

The aim of the work was to determine the optimal surface preparation and roughness in combination with the hardness-measurement method, which would provide the lowest measurement uncertainty when testing aluminium alloys. In order to determine the effect of different surface-preparation techniques and the resulting surface roughness on the hardness results, hardness testing by Brinell (HBW), Vickers (HV) and Rockwell (HRB) was carried out.

In the first section of the paper we present the tested material and provide experimental conditions together with the used statistical calculations. The scatter and measurement uncertainty of the hardness-measurement results obtained with three different methods on nine samples (cases) prepared by different milling conditions are presented.

\section{MATERIAL}

The exemplary material used for this investigation was 2xxx series D60 aluminium alloy 2030 ( $\mathrm{AlCuMgPb}$ ) in the T6 condition, manufactured from one batch of homogenous material.

The hardness measurements were first performed on specimens in the form of square blocks $(10 \times 10 \times$ 100) $\mathrm{mm}$ which were cut from extruded rods of a $20 \mathrm{~mm}$ diameter and milled with standard conditions (parameters described as reference - case B, see Table 1). Then from these blocks the cylinder specimens were cut for further analysis.

Due to the statistical relevance of the results, measurements were carried out on the same tested material according to the Brinell, Vickers and Rockwell methods, respectively.

\section{EXPERIMENTAL PART}

\subsection{Hardness measurements}

The hardness measurements were performed using three hardness test methods: Rockwell (HRB), Brinell (HBW) and Vickers (HV). The Brinell hardness test was performed according to the SIST EN ISO 6506-1:2014 standard $^{9}$ using an Innovates NEXUS 7501 testing machine with a 2.5 -mm-diameter ball and a load of $62.5 \mathrm{kgf}$ (HBW2.5/62.5). The Vickers hardness test was performed according to the SIST EN ISO 6507-1:2018 standard $^{10}$ on a Wilson Instrument Tukon 2100B testing machine with a load of $10 \mathrm{kgf}$ (HV10). The Rockwell hardness test (HRB) was performed according to the latest ISO standard SIST EN ISO 6508-1:2016, ${ }^{11}$ which requires that the test is carried out on a surface that is smooth and even, free from oxide scale, lubricants and foreign material. In the case of the Rockwell hardness test, a Wilson Instruments B2000 testing machine was used, applying load of $100 \mathrm{kgf}$ and using a $1.587-\mathrm{mm}$ diameter ball.

\subsection{Surface roughness}

Surface texture is a random deviation from the nominal surface that forms the three-dimensional topography of the surface. For an easier characterization and classification of different surfaces, roughness parameters were developed and standardized. Among the parameters for quantifying surface roughness based on tactile profile sections, $R_{\mathrm{z}}$ (maximum peak to valley height) and $R_{\mathrm{a}}$ (arithmetic mean deviation of the profile) are the most popular ones. If the parameters are evaluated from a 2D profile they are denoted with the capital letter R. If the parameters are evaluated from a 3D surface, the parameters are denoted with the capital letter S.

The roughness parameters, which are the average roughness $\left(S_{\mathrm{a}}\right)$ and ten-point heigh $\left(S_{\mathrm{z}}\right)$, were evaluated on the $3 \mathrm{D}$ surface, and therefore denoted with the capital letter $S$. The ten point height of the surface is an extreme parameter defined as the average value of the absolute heights of the five highest peaks and the depths of the deepest pits or valleys within the sampling area. A de- 
Table 1: The study Cases (A-I) for different conditions of surface preparation

\begin{tabular}{|c|c|c|c|c|c|c|}
\hline \multirow{2}{*}{ Case } & \multirow{2}{*}{$\begin{array}{l}\text { Rotation speed of the } \\
\text { cutting mill } n\left(\mathrm{~min}^{-1}\right)\end{array}$} & \multirow{2}{*}{$\begin{array}{c}\text { Feed rate } \\
V_{\mathrm{f}}(\mathrm{mm} / \mathrm{min})\end{array}$} & \multirow{2}{*}{$\begin{array}{l}\text { Depth of cut } \\
V_{\mathrm{z}}(\mathrm{mm})\end{array}$} & \multirow{2}{*}{$\begin{array}{l}\text { Aditional surface } \\
\text { preparation }\end{array}$} & \multicolumn{2}{|c|}{ Roughness } \\
\hline & & & & & $S_{\mathrm{a}}(\mu \mathrm{m})$ & $S_{\mathrm{Z}}(\mu \mathrm{m})$ \\
\hline A & 450 & 150 & 0.5 & & 0,78 & 10,70 \\
\hline $\mathrm{B}$ & 750 & 150 & 0.5 & $\mathrm{R}$ & 1,31 & 14,70 \\
\hline $\mathrm{C}$ & 950 & 150 & 0.5 & & 0,64 & 7,10 \\
\hline D & 750 & 73 & 0.5 & & 0,84 & 11,10 \\
\hline $\mathrm{E}$ & 750 & 235 & 0.5 & & 0,68 & 7,40 \\
\hline $\mathrm{F}$ & 750 & 150 & 0.2 & & 0,74 & 9,00 \\
\hline $\mathrm{G}$ & 750 & 150 & 1 & & 0,65 & 8,40 \\
\hline $\mathrm{H}$ & 750 & 150 & 0.5 & G & 0,33 & 8,80 \\
\hline I & 750 & 150 & 0.5 & $\mathrm{P}$ & 0,22 & 6,20 \\
\hline
\end{tabular}

Note: $\mathbf{R}$ - Milled sample named as Reference case, $\mathbf{G}$ - Grinded by grinding paper with 500 granularity, $\mathbf{P}-$ Polished with $3 \mu \mathrm{m}$ particles

tailed description of these parameters can be found in ${ }^{12}$. The measurement of the 3D topography and the associated roughness parameters were obtained by using a Talysurf Series 2 stylus profilometer. For all specimens, the surface evaluation window was $(1.25 \times 1.25) \mathrm{mm}$, with a sampling interval of $10 \mu \mathrm{m}$, and a measurement speed of $0.05 \mathrm{~mm} / \mathrm{s}$. The 3D roughness parameters were calculated using TalyMap Gold. Prior to the calculation, Gaussian filtering was used with $0.25-\mathrm{mm}$ cut-off lengths.

\section{STATISTICAL CALCULATIONS}

The statistical analysis of the experimental data included calculations of the following parameters ${ }^{13}$ :

- average value of the measurements $(\bar{x})$ according to (1),

- standard deviation (s) according to (2) and (3),

- measurement uncertainty ( $u$ ) according to (4) and (5)

- repeatability (bu) according to (6).

The calculations were repeated for each set of measurements using the following equations. ${ }^{13}$ The average value of the measurements:

$$
\bar{x}=\frac{1}{n} \sum_{i=1}^{n} x_{i}
$$

Where $n, x_{i}$ represent the number of the set of measurements and the individual measurement, respectively. The standard deviation $s$ was calculated using the following equations:

$$
\begin{gathered}
s=\sqrt{\frac{\sum_{i-1}^{n}\left(x_{i}-\bar{x}\right)^{2}}{n-1}} \\
s=\frac{s}{\bar{x}} \cdot 100 \%
\end{gathered}
$$

The measurement uncertainty and the repeatability of the measurements follow the next equations:

$$
u=\frac{s}{\sqrt{n}}
$$

$$
\begin{gathered}
u=\frac{u}{\bar{x}} \cdot 100 \% \\
b=\frac{x_{\text {max }}-x_{\min }}{\bar{x}}
\end{gathered}
$$

With $x_{\max }, x_{\min }$ representing the minimum and the maximum values from the set of measurements.

Using statistical techniques, the standard deviation, repeatability, and measurement were analysed, which are all the parameters required by the automotive industry. ${ }^{14}$ The use of just one single parameter, the standard deviation, is not sufficient. Standard deviation is mainly affected by the inhomogeneity of the material, while repeatability and measurement uncertainty take into account the reliability of the used measuring method and the accuracy of the testing equipment. ${ }^{15}$ As shown in a previous investigation on tensile testing, ${ }^{16}$ there are many different factors influencing the measurement uncertainty, but not directly reflected in the standard deviation.

\section{STUDY CASES}

In this section the impact of the surface preparation and the surface roughness on the hardness measurements was analysed.

First, the impact of surface machining and the preparation on the hardness measurements, mainly from the measurement-uncertainty point of view were investigated. Nine specimens named "study cases" specified as Case A to Case I, were prepared where the surface-preparation parameters were varied: the rotation speed of the cutting mill $(n)$, the feed rate $\left(V_{\mathrm{f}}\right)$, the depth of cut $\left(V_{\mathrm{z}}\right)$ and the impact of the post-processing conditions, i.e., grinding and polishing. The cases are described in Table 1. For each study case at least 5 measurements were performed for each specimen according to the HBW, HRB and HV methods, respectively.

Furthermore, the impact of surface curvature on the hardness testing was analysed. The measurements were performed on cylindrical test-type specimens with different diameters of 8, 10, 11, 12, 14, 16, 19 and $20 \mathrm{~mm}$. For each diameter, three samples were prepared, where for 


\section{A. GUŠTIN et al.: ANALYSIS OF THE SURFACE-PREPARATION EFFECT ON THE HARDNESS-MEASUREMENT ...}

each five measurements were performed. The statistical deviation of the measurment results was then analysed and graphically depicted.

\section{RESULTS}

\subsection{Hardness-measurement results for different sur- face preparations.}

Nine specimens of material D60, named as case specified from A to I, were tested. The hardness measurements were performed for each case with different surface treatments, briefly described in Table 1. As can be seen from Table 1, the roughest surface $\left(S_{\mathrm{a}}=1.31\right)$ is represented by Case B (reference case $-\mathrm{R}$ ), the smoothest one by Case I $\left(S_{\mathrm{a}}=0.22\right)$.

Due to the statistical relevance of the results, at least five hardness measurements were performed for each case, separately for each test method (HBW, HV and HRB). The obtained results of the hardness measure- ments together with the statistical calculations are presented in Tables 2 to 4 . The largest difference in the average hardness values was obtained for the Vickers test in the range 124-131 HV, then for Brinell test in the range 118-121 HBW and for Rockwell test, 68-69 HRB.

\subsection{Hardness results obtained for different surface curvatures.}

The obtained results of hardness measurements depending on the surface curvature are summarized in Table 5 for Brinell and for Rockwell test. For each diameter three samples were prepared, where five parallel measurements were performed. The average values were taken into the consideration in the subsequent analysis. The obtained results together with the statistical calculations are presented in Table 5. For the Brinell test the results are in the range 115-118 HBW, for Rockwell test the results are in the range 64-68 HRB.

Table 2: Statistical calculations for Brinell hardness test for different milling cases (Table 1)

\begin{tabular}{|c|c|c|c|}
\hline Measurements/ Cases & Average value HBW $x$ & Standard deviation $s$ & Measurement uncertainty $u$ \\
\hline A & 120,61 & 1,03 & 0,46 \\
\hline B & 121,29 & 1,18 & 0,53 \\
\hline C & 121,54 & 1,20 & 0,53 \\
\hline D & 118,77 & 0,88 & 0,39 \\
\hline E & 120,11 & 0,75 & 0,33 \\
\hline F & 119,17 & 0,53 & 0,24 \\
\hline G & 118,46 & 0,25 & 0,11 \\
\hline H & 119,29 & 0,72 & 1,42 \\
\hline I & 120,71 & 1,07 & 0,32 \\
\hline
\end{tabular}

Table 3: Statistical calculations for Vickers test for different milling cases (Table 1)

\begin{tabular}{|c|c|c|c|}
\hline Measurements/ Cases & Average value HV $x$ & Standard deviation $s$ & Measurement uncertainty $u$ \\
\hline A & 131,56 & 2,69 & 1,20 \\
\hline B & 126,54 & 1,55 & 0,69 \\
\hline C & 125,44 & 1,40 & 0,63 \\
\hline D & 129,86 & 1,91 & 0,85 \\
\hline E & 129,04 & 3,73 & 1,67 \\
\hline F & 125,52 & 1,19 & 0,53 \\
\hline G & 126,54 & 4,01 & 1,80 \\
\hline H & 127,54 & 0,74 & 0,28 \\
\hline I & 124,54 & 1,23 & 0,33 \\
\hline
\end{tabular}

Table 4: Statistical calculations for Rockwell test for different milling cases (Table 1)

\begin{tabular}{|c|c|c|c|}
\hline Measurements/ Cases & Average value HRB $x$ & Standard deviation $s$ & Measurement uncertainty $u$ \\
\hline A & 69,30 & 0,60 & 0,27 \\
\hline B & 69,68 & 1,02 & 0,46 \\
\hline C & 68,90 & 0,41 & 0,18 \\
\hline D & 67,92 & 2,17 & 0,97 \\
\hline E & 69,34 & 0,38 & 0,17 \\
\hline F & 69,08 & 0,31 & 0,14 \\
\hline H & 68,70 & 0,35 & 0,16 \\
\hline I & 68,48 & 0,50 & 1,30 \\
\hline
\end{tabular}


A. GUŠTIN et al.: ANALYSIS OF THE SURFACE-PREPARATION EFFECT ON THE HARDNESS-MEASUREMENT ...

Table 5: Hardness measuring results obtained by Brinell (left) and Rockwell (right) test performed for cylinders with different diameters

\begin{tabular}{|c|c|c|c|c|c|c|c|c|}
\hline $\begin{array}{l}\text { Diameter } \\
d(\mathrm{~mm})\end{array}$ & $\begin{array}{c}\text { Average values of hardness } \\
\text { measurements } \mathbf{H B W}\end{array}$ & $s(\%)$ & $u(\%)$ & $b(\%)$ & $\begin{array}{c}\text { Average values of hardness } \\
\text { measurements } \mathbf{H R B}\end{array}$ & $s(\%)$ & $u(\%)$ & $b(\%)$ \\
\hline 8 & 115,8 & 0,34 & 0,09 & 1,21 & 64,8 & 0,34 & 0,09 & 1,08 \\
\hline 10 & 116,0 & 0,74 & 0,19 & 2,70 & 66,6 & 0,26 & 0,06 & 0,90 \\
\hline 11 & 116,7 & 2,11 & 0,54 & 8,61 & 65,5 & 1,31 & 0,33 & 5,19 \\
\hline 12 & 117,9 & 0,79 & 0,20 & 3,44 & 66,3 & 0,35 & 0,09 & 1,35 \\
\hline 14 & 117,4 & 2,39 & 0,43 & 9,29 & 65,3 & 2,16 & 0,39 & 7,20 \\
\hline 16 & 118,0 & 2,60 & 0,47 & 11,20 & 66,5 & 1,53 & 0,28 & 5,56 \\
\hline 19 & 115,4 & 1,23 & 0,31 & 4,58 & 67,3 & 1,12 & 0,29 & 3,56 \\
\hline 20 & 115,0 & 1,74 & 0,45 & 6,53 & 68,0 & 1,41 & 0,36 & 4,26 \\
\hline
\end{tabular}

\section{DISCUSSION}

\subsection{Effect of different surface preparation on the hard- ness measurement accuracy.}

The obtained results, presented in the form of standard deviation, measurement uncertainty and repeatability, are compared to the reference conditions $\left(n 750 / V_{\mathrm{f}}=\right.$ $\left.150 / V_{\mathrm{f}}=0.5\right)$, depicted as Case B in Table 1.

From the results obtained for the Brinell method it can be observed that the impact of the surface preparation was the smallest among all three hardness-measurement methods. For all Cases the calculated statistical parameters, including the standard deviation (less than 1\%) and measurement uncertainty (less than $0.5 \%$ ), fulfilled the required conditions, defined by the automotive industry (Figure 2). Any changes of the rotational speed of the mill cutter did not have a significant effect on the measurement accuracy, in the range from $0.38 \%(0.46)$ for $450 \mathrm{~min}^{-1}$ to $0.44 \%$ (0.53) for $950 \mathrm{~min}^{-1}$, respectively. Increasing the depth of cut (from 0.5 to $1.0 \mathrm{~mm}$ ) and the feed rate (from $150 \mathrm{~mm} / \mathrm{min}$ to $235 \mathrm{~mm} / \mathrm{min}$ ) resulted in a reduced measurement uncertainty below $0.3 \%$ (Figure 1B), which is most visible for Case G (standard deviation dropped to $0.21 \%(0.25)$ and measurement uncertainty to $0.09 \%(0.11)$.
From the results obtained for the Vickers method, it can be observed that the impact of the surface preparation was the greatest because the test is the most sensitive to the state of the surface finish. The standard deviation and the measurement uncertainty were reduced by increasing the rotation speed, and by decreasing the feed rate and the depth of cut (Figure 2a). Based on the results it can be concluded that for the Vickers hardness measurement, the best measurement accuracy is obtained when the following conditions are applied: high spindle speed of $950 \mathrm{~min}^{-1}(1.12 \%)$, medium feed rate of $150 \mathrm{~mm} / \mathrm{min}(1.23 \%)$ and low depth of cut of $0.2 \mathrm{~mm}$ $(0.95 \%)$, which is depicted in Figure 2b). Under these conditions, the standard deviation is expected to be around $1 \%$ and the measurement uncertainty less than $0.5 \%$. However, by reducing the surface roughness (from $S_{\mathrm{a}}=1.31$ to $S_{\mathrm{a}}=0.33 \mu \mathrm{m}$ ), obtained by post processing with surface grinding, reducing the measurement uncertainty down to $0.26 \%$ (0.33) can be achieved (Case $\mathrm{H})$. On the other hand, a further reduction in surface roughness to $S_{\mathrm{a}}=0.22 \mu \mathrm{m}$ (Case I), obtained by polishing the surface did not bring any additional improvement in the measurement accuracy.

In the case of the Rockwell test, similar conclusions to the Brinell test can be noted. Increasing the spindle speed, feed rate and depth of the milling cut led to a re-

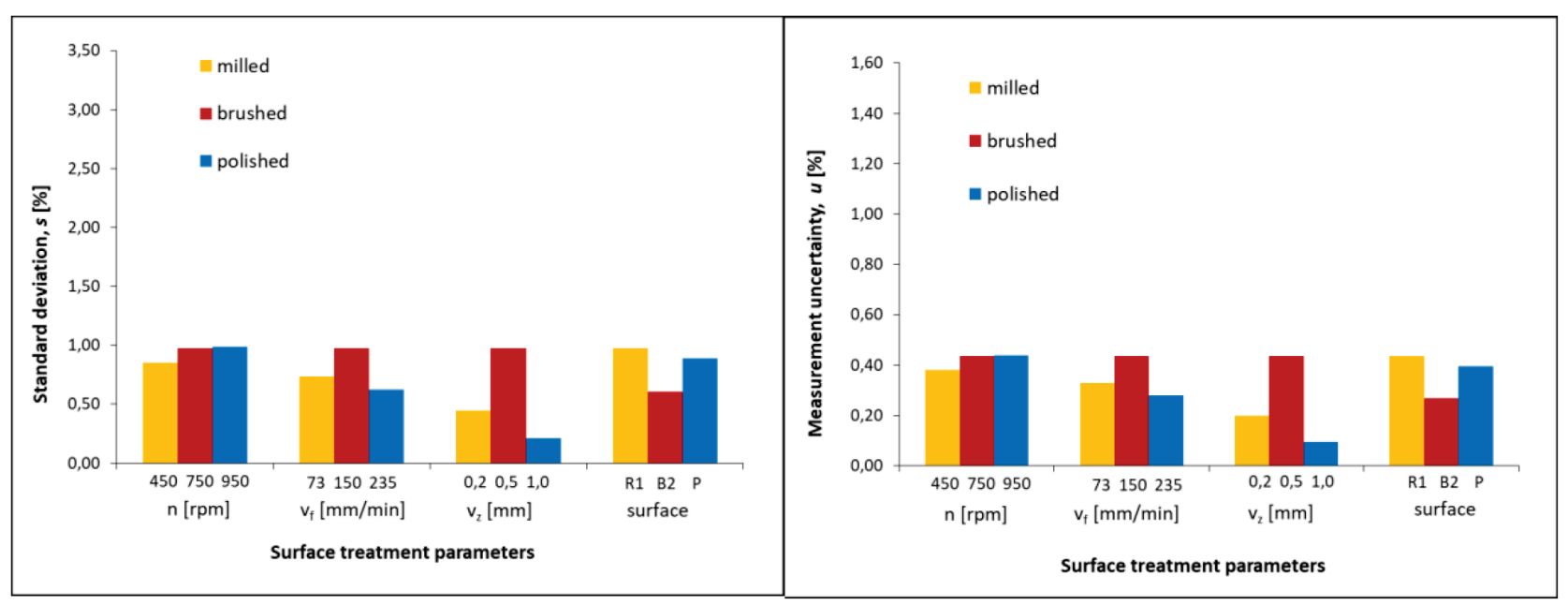

Figure 1: (Left) Standard deviation $(s)$ and (Right) measurement uncertainty $(u)$ vs. different conditions of surface preparation for the Brinell test 
A. GUŠTIN et al.: ANALYSIS OF THE SURFACE-PREPARATION EFFECT ON THE HARDNESS-MEASUREMENT ...

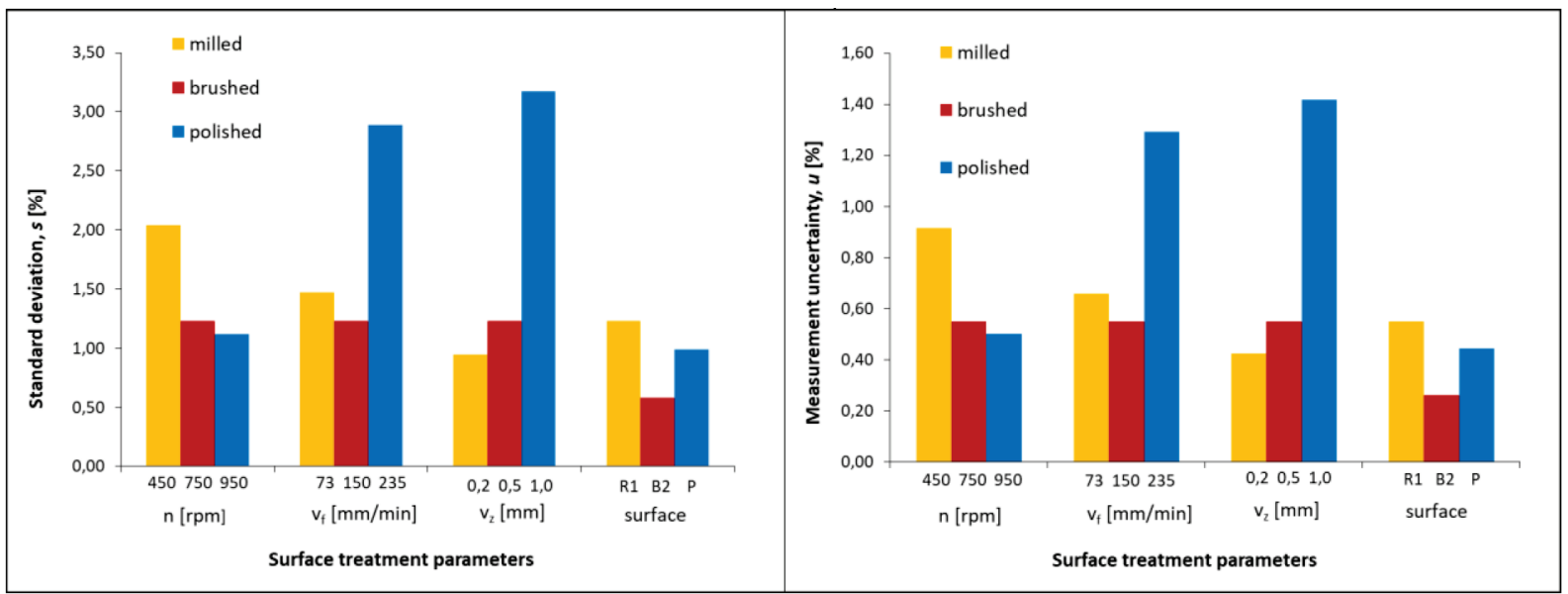

Figure 2: (Left) Standard deviation $(s)$ and (Right) measurement uncertainty $(u)$ vs. different conditions of surface preparation for the Vickers test

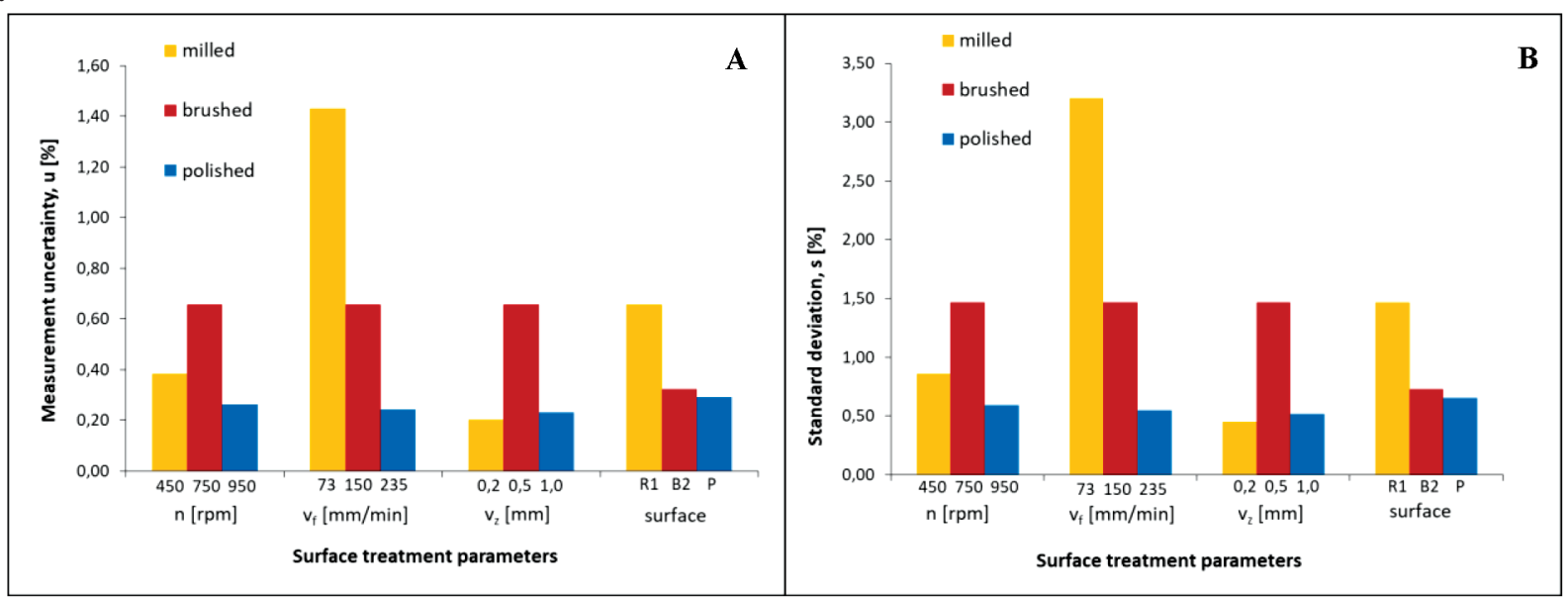

Figure 3: (Left) Standard deviation $(s)$ and (Right) measurement uncertainty $(u)$ vs. different conditions of surface preparation for the Rockwell test
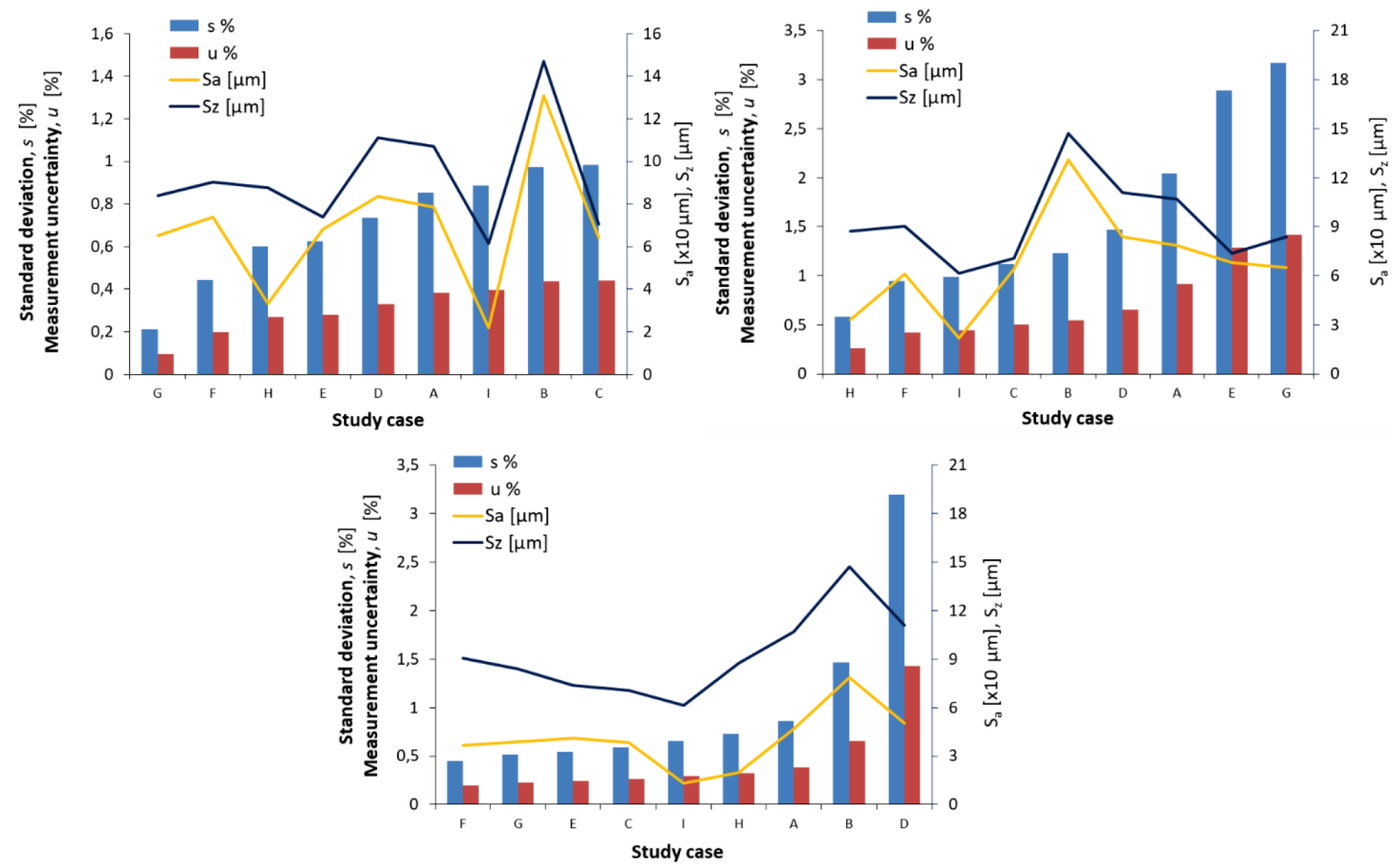

Figure 4: Correlation between surface roughness and statistical error parameters for (top left) HBW; (top right) HV and (bottom) HRB test 
duction in the standard deviation and the measurement uncertainty. Compared to the reference conditions (Case B, Table 1), increasing the rotation speed $n$ from $750 \mathrm{~min}^{-1}$ to $950 \mathrm{~min}^{-1}$ brings to standard deviation a reduction from $1.5 \%(1.02)$ to $0.6 \%(0.41)$ as well as the measurement uncertainty from $0.66 \%$ to $0.26 \%$. Also, an increase of the feed rate from 73 to $235 \mathrm{~mm} / \mathrm{min}$ reduces the standard deviation from $3.2 \%$ to $0.55 \%$ as well as the measurement uncertainty from $1.43 \%$ to $0.24 \%$. The reduction of these two deviation parameters down to $0.65 \%$ and $0.29 \%$ respectively, was also achieved by subsequent post polishing (Case I), as depicted in Figure 3b.

If we now compare the surface preparation parameters (Table 1) with the achieved surface roughness and calculated measurement uncertainty (Figure 4) it can be concluded that for the Brinell test the best measurement accuracy (low standard deviation $S_{\%}$ and low measurement uncertainty $u$ ) can be achieved when the surface roughness is less than $0.6 \mu \mathrm{m}$ for $S_{\mathrm{a}}$ and less than $10 \mu \mathrm{m}$ for $S_{\mathrm{z}}$. These surface conditions are reached by milling aluminium at $750 \mathrm{~min}^{-1}$, with a feed rate of $150 \mathrm{~mm} / \mathrm{min}$ and a milling depth of $0.2-1.0 \mathrm{~mm}$. The same applies to the Vickers and Rockwell test (Figure 4) methods; how- ever, the Vickers method requires additional grinding or polishing of the surface.

\subsection{Effect of surface curvature on the hardness mea- surement accuracy.}

From the hardness measurement results obtained for different cylinder diameters, graphically presented in Figure 5a and Figure 6a, it can be concluded that the curvature of the surface did not have any obvious influence on the measured hardness values.

The same applies to the measurement uncertainty when the Brinell method was used.

For the Rockwell method no curvature correction was used. As shown in Figure $\mathbf{6 b}$, the measured hardness values decrease with the increase in the surface curvature, while the measurement uncertainty is always below $1 \%$. It was also noticed, that for the diameters below $10 \mathrm{~mm}$, indentations become oval in appearance and diagonals show excessive deviation (above $5 \%$ ). Therefore, the measurements made on surfaces with a diameter smaller than $10 \mathrm{~mm}$ are not relevant.

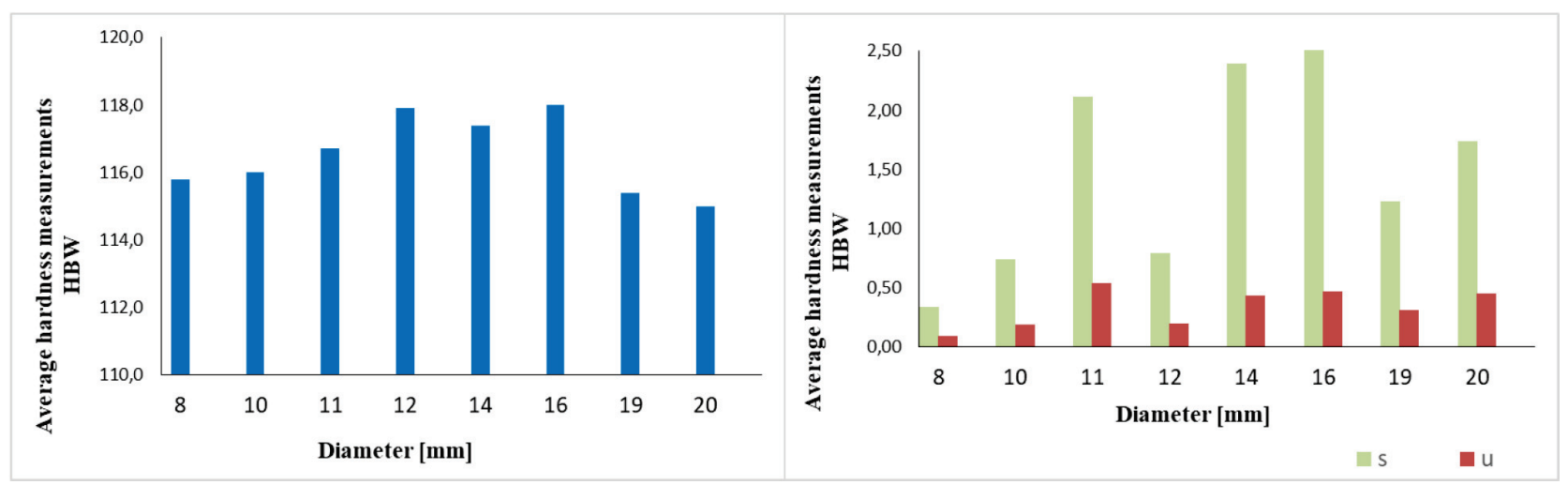

Figure 5: (Left) Hardness measuring results obtained for the Brinell test performed on curved surface and (Right) graphical representation of statistical error parameters (standard deviation and measurement uncertainty)

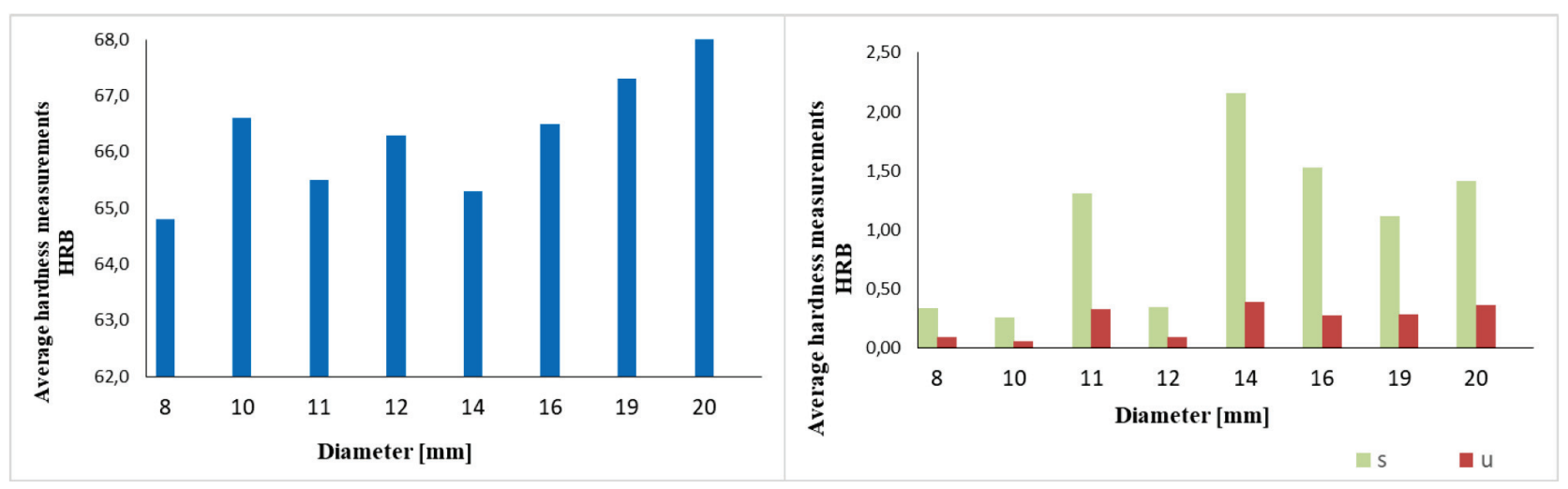

Figure 6: (Left) Average hardness measuring results obtained for the Rockwell test performed on curved surface and (Right) graphical representation of statistical error parameters (standard deviation and measurement uncertainty) 


\section{CONCLUSIONS}

Under the different surface-preparation conditions considered in the experimental work described above, the following conclusions can be drawn.

In the case of the Brinell and Rockwell test, increasing the depth of cut and feed rate, as well as applying additional surface grinding, reduces the measurement uncertainty $u$, which can be reduced down to for Brinell and $0.09 \%$ and $0.23 \%$ for Rockwell.

In the case of the Vickers test the standard deviation s and the measurement uncertainty $u$ can be reduced by increasing the rotation speed, as well as by decreasing the feed rate velocity and the depth of cut.

Comparing the surface preparation parameters with the achieved roughness indicates that for the Brinell and Rockwell test the best measurement accuracy for aluminium alloys can be achieved when the surface roughness is lower than $S_{\mathrm{a}}<0.6 \mu \mathrm{m}$ and $S_{\mathrm{z}}<10 \mu \mathrm{m}$. The Vickers method requires additional grinding or polishing of the surface.

The changes in the surface curvature do not have any obvious influence on the measured hardness values when it comes to the Brinell testing. However, for the Rockwell test, the values of the measured hardness decrease with the increase in the surface curvature.

It was found that measurements performed on samples with a diameter smaller than $10 \mathrm{~mm}$, are not relevant due to deformation and non-symmetry of the indent.

\section{Acknowledgment}

This research was a part of an inter-laboratory proficiency project carried out between the industry and the materials testing facility at the Institute of Metals and Technology, which was partly financed by the Slovenian Research Agency (research core funding No. P2-0050) and the company Impol.

\section{REFERENCES}

${ }^{1}$ E. Broitman, Indentation hardness Measurements at Macro-, Micro-, and Nanoscale - A critical Overview, Tribol Lett., 65:23 (2017) 1-18, doi:10.1007/s11249-016-0805-5
${ }^{2}$ A. Z. Guštin, B. Žužek, B. Podgornik, V. Kevorkijan, The uncertainty of hardness measurements related to the measurement method, surface preparation and range of the measurements, Materials and technology, 53 (2019) 6, 897-904, doi:10.17222/mit.2019.098

${ }^{3}$ M. C. Dijmarescu, M. R. Dijmarescu, Estimation of Vickers hardness uncertainty for a heterogeneous welded joint (S235JR+AR and X2CrNiMo17-12-2), IOP Conference Series: Materials Science and Engineering, 227 (2017) 012035, doi:10.1088/1757-899X/227/1/ 012035

${ }^{4}$ P. H. Osanna, M. N. Durakbasa, L. Si, A. Afjehi-Sadat, Quality Management and Metrology in Intelligent Manufacturing, IFAC Proceedings Volumes, 34, (2001) 17, 129-134, doi:10.1016/S14746670(17)33268-8

${ }^{5}$ G. Verdins, D. Kanaska, V. Kleinbergs, Selection of the method of hardness test, $12^{\text {th }}$ International Scientific Conference - Engineering for rural development, Jelgava, 2013, 217-220

${ }^{6}$ Y. Xia, M. Bigerelle, J.Marteau, P. E. Mazeran, S. Bouvier, A. Iost, Effect of Surface Roughness in the Determination of the Mechanical properties of material using nanoindentation test, Scanning, 36 (2014)134-144, doi:10.1002/sca.21111

${ }^{7}$ I. Maslenikov, A. Useinov, A. Birykov, V. Reshetov, Reducing the influence of the surface roughness on the hardness measurement using instrumented indentation test, Materials Science and Engineering, 256 (2017) 1-5, doi:10.1088/1757-899X/256/1/012003

${ }^{8}$ A. M. Hassa, A. S. Al-Bsharat, Influence of burnishing process on surface roughness, hardness, and microstructure of some non-ferrous metals, Wear, 199 (1996) 1-8, doi:10.1016/0043-1648(95)06847-3

${ }^{9}$ ISO 6506-1:2014 - Brinell hardness test, Presentation and indication ISO Committee, Geneve

${ }^{10}$ ISO 6507-1:2006 - Vickers hardness test, Presentation and indication ISO Committee, Geneve

${ }^{11}$ ISO 6508-1:2015 - Rockwell hardness test, Presentation and indication ISO Committee, Geneve

${ }^{12}$ M. Sedlaček, B. Podgornik, J. Vižintin, J. Možina: Use of parameters planning surface texturing, Proceedings of the $3^{\text {rd }}$ AMES International Conference of Development and implementation of enhanced technologies, Ljubljana, 2011, 147-154

${ }^{13}$ S. Klysz, J. Lisiecki, Selected problems of measurement uncertainty - part I, Technical Sciences, 8 (2008) 1-22, doi:10.2478/v10022008- 0018-8

${ }^{14} \mathrm{~T}$. Polzin, Determination of uncertainty for hardness measurement: proposal of the standard, available software, Accreditation and Quality Assurance, 8 (2003), 12, 564-568, doi:10.1007/s00769-0030690-0

${ }^{15}$ A. S. Morris, R. Langari, Measurement Uncertainty, in: Measurement and Instrumentation, Theory and Application, ButterworthHeinemann, NY, 2012

${ }^{16}$ B. Podgornik, B. Žužek, M. Sedlaček, V. Kevorkijan, B. Hostej, Analysis of Factors Influencing Measurement Accuracy of Al Alloy Tensile Test Results, Measurement Science Review, 16 (2016), 1, 1-7, doi:10.1515/msr-2016-0001 